\title{
Review
}

\section{Smart drugs and neuroenhancement: what do we know?}

\author{
Massimiliano Esposito ${ }^{1}$, Giuseppe Cocimano ${ }^{1}$, Federica Ministrieri ${ }^{1}$, Giuseppe Li Rosi ${ }^{2}$, \\ Nunzio Di Nunno ${ }^{3}$, Giovanni Messina ${ }^{4}$, Francesco Sessa ${ }^{4, *, \dagger}$, Monica Salerno ${ }^{1, *, \dagger}$ \\ ${ }^{1}$ Department of Medical, Surgical and Advanced Technologies “G.F. Ingrassia”, University of Catania, 95121 Catania, \\ Italy, ${ }^{2}$ Department of Law, Criminology, Magna Graecia University of Catanzaro, 88100 Catanzaro, Italy, ${ }^{3}$ Department \\ of History, Society and Studies on Humanity, University of Salento, 73100 Lecce, Italy, ${ }^{4}$ Department of Clinical and \\ Experimental Medicine, University of Foggia, 71122 Foggia, Italy
}

\section{TABLE OF CONTENTS}

1. Abstract

2. Introduction

3. Materials and methods

3.1 Systematic review

3.2 Inclusion and exclusion criteria

3.3 Quality assessment and data extraction

3.4 Characteristics of eligible studies

4. Results

5. Discussion

6. Conclusions

7. Author contributions

8. Ethics approval and consent to participate

9. Acknowledgment

10. Funding

11. Conflict of interest

12. References

\section{Abstract}

Introduction: Smart drugs are among the most common drugs used by students. It is estimated that they are second in incidence after cannabis. Although they are usually used for diseases such as attention deficit hyperactivity disorder (ADHD) and dementia, in most cases the use of smart drugs is illegal and without a prescription. Methodological issues: A systematic review was conducted according to PRISMA guidelines. SCOPUS, Medline (using PubMed as a search engine), Embase, Web of Sciences, and Google Scholar were used as search engines from January 1, 1980 to June 1, 2021 to evaluate the association between smart drugs and neuro-enhancement. A total of 4715 articles were collected. Of these, 295 duplicates were removed. A total of 4380 articles did not meet the inclusion criteria. In conclusion, 48 articles were included in the present systematic review. Results: Most of the studies were survey studies, 1 was a prospective longitudinal study, 1 was a crossover study, and 1 was an experimental study in an animal model (rats). The largest group of consumers was school or university students. The most frequent reasons for us- ing smart drugs were: better concentration, neuro enhancement, stress reduction, time optimization, increased wake time, increased free time, and curiosity. There are conflicting opinions, in fact, regarding their actual functioning and benefit, it is not known whether the benefits reported by consumers are due to the drugs, the placebo effect or a combination of these. The real prevalence is underestimated: it is important that the scientific community focus on this issue with further studies on animal models to validate their efficacy.

\section{Introduction}

The use of illicit smart drugs among college students is second only to cannabis [1]. Smart drugs are generally prescribed for subjects with attention deficit hyperactivity disorder (ADHD), Alzheimer disease, Parkinson disease, and dementia [2]. However, the use of smart drugs among healthy people has been increasing in recent years [3-6]. In the 2010s, the production of smart drugs tripled [7]. The current prevalence of use in the American student 


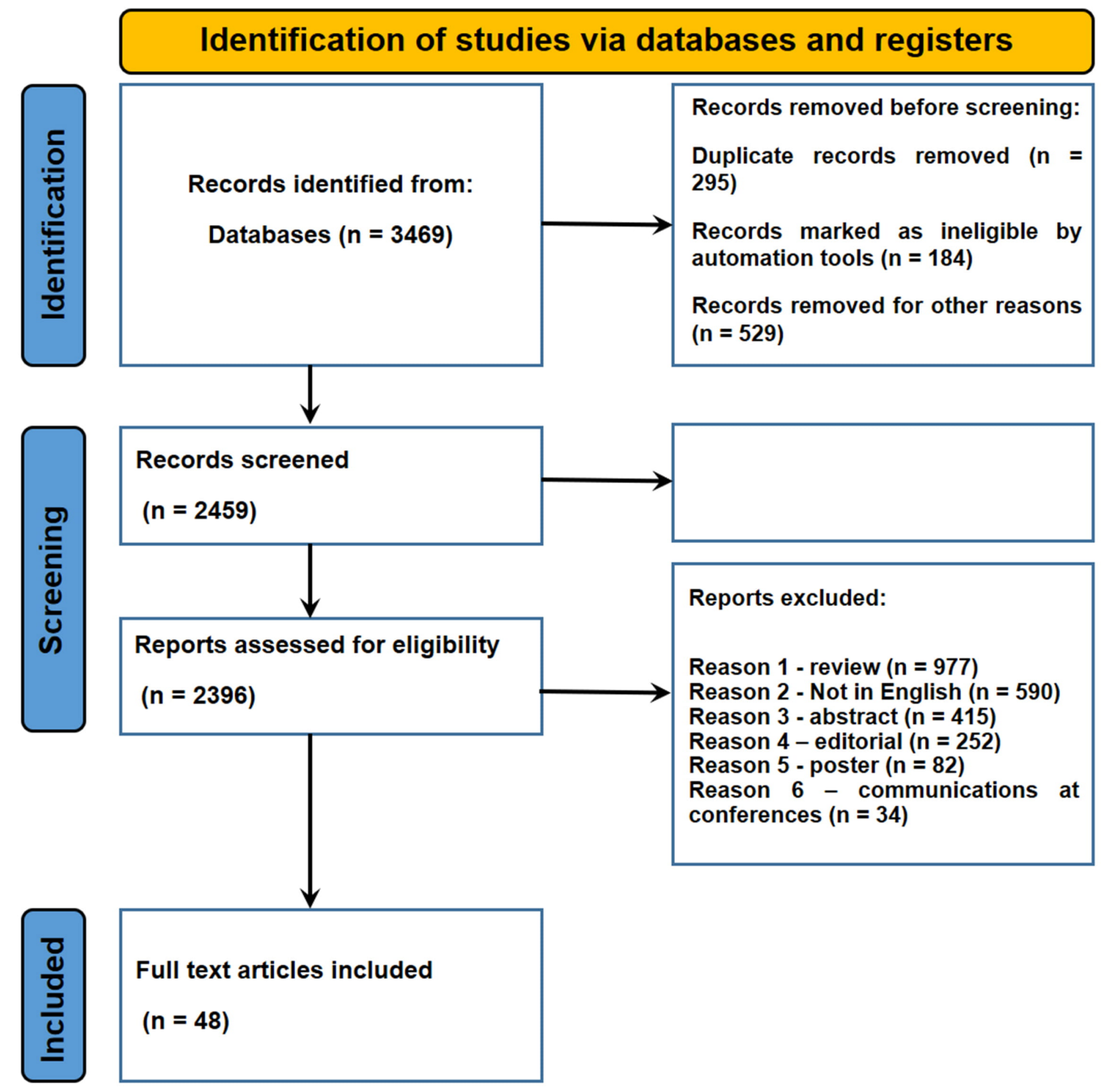

Fig. 1. Flow diagram illustrating included and excluded studies in this systematic review.

population has been estimated to be between 5-35\% [8]. Prevalence rates in Europe are unclear, with less than $10 \%$ reported in the UK, which was likely due to low availability [9]. In 2015, 6/8\% of German university students used smart drugs [10]. Despite the increase in the prevalence of smart drug users, the use of these substances appears to be underestimated [11]. The most frequently used smart drugs and nootropics are caffeine, modafinil, methylphenidate, and amphetamines. One explanation could be that they are the ones that are more easily obtained even on the black market or through a friend, for example, at school or university. In addition, the easy administration (oral or inhalation) also contributes to ease of consumption [1, 6, 8, 12]. The main reasons for the increase of smart drug use/abuse were: improvement of cognitive functions, reduction of stress, increase in free time, and increase in school and work performance [2-8]. Some studies have shown moderate cognitive improvements in attention and reduced sleep, with increased confidence [12]. Instead, other studies showed that smart drugs only had a placebo effect. The main data about commonly used smart drugs are summarized in Table 1 (Ref. [13-36]). However, even if the focus on cognitive enhancers is high, the information about their actual functioning is little [4-9]. Smart drugs are a public safety problem, because they are often taken in combination with other drugs with an increased risk of interaction. Furthermore, they still have partially unknown side effects (increased risk of suicide, psychiatric disorders, increased cardiovascular risk). This aspect plays a crucial role in public health, considering the increase in the use of smart drugs in young and worker populations [13-17, 37, 38]. To date, there are few longitudinal and experimental studies on the effects of smart drugs, certainly also for ethical reasons [812]. However, their use is increasing, even if the benefits and side effects of these drugs are not well known. Therefore, it is essential that studies are also implemented on animal models to know the real effects. The risk of addiction and abuse is still debated. However, psychosis, insomnia, and irritability are common [37, 38]. 
Table 1. Main smart drugs, routes of administration, cognitive effects, approved and off-label use.

\begin{tabular}{|c|c|c|c|c|}
\hline Drug & Main route of administration & Cognitive effects & Approved use & Off label or investigational use \\
\hline Methylphenidate [13, 14] & Oral administration & $\begin{array}{l}\text { Increased memory, attention, concentration and } \\
\text { wakefulness }\end{array}$ & ADHD, narcolepsy & $\begin{array}{l}\text { Opiate withdrawal syndrome, chronic fatigue } \\
\text { syndrome, major depressive disorder }\end{array}$ \\
\hline Modafinil [15-17] & Oral administration & Increased memory and wakefulness & Narcolepsy & $\begin{array}{l}\text { Doping, ADHD, multiple sclerosis, depression } \\
\text { syndrome, opiate withdrawal syndrome }\end{array}$ \\
\hline Amphetamine [18-20] & $\begin{array}{c}\text { Oral administration, snorting, intravenous } \\
\text { injection }\end{array}$ & $\begin{array}{c}\text { Mood enhancement, increased attention and } \\
\text { wakefulness }\end{array}$ & ADHD, narcolepsy, obesity & Doping \\
\hline Armodafinil [21] & Oral administration & Increased wakefulness & $\begin{array}{c}\text { Excessive daytime sleepiness associated } \\
\text { with obstructive sleep apnea, narcolepsy, } \\
\text { shift-work disorder }\end{array}$ & $\begin{array}{l}\text { ADHD, chronic fatigue syndrome, major } \\
\text { depressive disorder }\end{array}$ \\
\hline MDMA (Ecstasy) [22-29] & Oral administration & $\begin{array}{l}\text { Mood enhancement, general wellbeing, } \\
\text { increased empathy }\end{array}$ & & Post-traumatic stress disorder, alcohol addiction \\
\hline Cocaine [30-33] & $\begin{array}{l}\text { Inhalation, chewing of coca leaves, } \\
\text { intramuscular injection, subcutaneous } \\
\text { injection, snorting, intravenous injection }\end{array}$ & $\begin{array}{l}\text { Mood enhancement, euphoria, sexual arousal, } \\
\text { loss of contact with reality, agitation }\end{array}$ & & Local anesthetic, vasoconstrictor \\
\hline Ketamine [34-36] & $\begin{array}{l}\text { Intravenous injection, intramuscular } \\
\text { injection, oral administration, snorting }\end{array}$ & $\begin{array}{l}\text { Dissociation, analgesia, dysphoria, delirium, } \\
\text { euphoria, difficulty concentrating, visual and } \\
\text { auditory hallucinations, amnesia, sedation }\end{array}$ & $\begin{array}{l}\text { Dissociative anesthesia, resistant } \\
\text { depression, acute pain treatment }\end{array}$ & $\begin{array}{l}\text { Bipolar disorder, post-traumatic stress disorder, } \\
\text { anxiety disorders, mood disorders }\end{array}$ \\
\hline
\end{tabular}




\section{Materials and methods}

\subsection{Systematic review}

A systematic review was conducted according to the PRISMA guidelines [36].

SCOPUS, Medline (using PubMed as the search engine), Embase, Web of Sciences, and Google Scholar were used as search engines from 1 January 1980 to 1 June 2021 to evaluate the association between smart drugs and neuroenhancement. Medical subject headings (meSH) was used with the following words: (smart drugs) AND (neuroenhancement); (smart drugs) AND (brain); (smart drugs) AND (cognitive); (smart drugs) AND (enhancement).

\subsection{Inclusion and exclusion criteria}

The following exclusion criteria were: (1) review, (2) articles not in English, (3) abstract, (4) editorial, (5) poster, and (6) communications at conferences. The inclusion criteria were: (1) Original Article, (2) Case Report, (3) articles in English, and (4) Animal Studies.

\subsection{Quality assessment and data extraction}

M.E. and G.C. initially evaluated all the articles, evaluating the title, the abstract, and the whole text. F.M. and M.E. reanalyzed the chosen articles independently. In cases of conflicting opinions concerning the articles, they were submitted to M.S.

\subsection{Characteristics of eligible studies}

A total of 4715 articles were collected. Of these, 295 duplicates were removed. A total of 4380 articles did not meet the inclusion criteria. In conclusion, 48 articles were included in the present systematic review (Fig. 1).

\section{Results}

Most of the studies were surveys. Only 1 was a longitudinal prospective study, 1 was a cross-over study, and 1 was an experimental study in an animal model (rats). Most of the studies involved students. In the majority of cases, the most used smart drugs were modafinil, methylphenidate, methamphetamine, and amphetamines. This systematic review showed that the most frequent reasons for using smart drugs were: better concentration, neuroenhancement, stress reduction, time optimization, increase in time awake, increase in free time, and curiosity. There are conflicting data on the prevalence of smart drug use among students, ranging from 2\% to $80 \%$ [3941]. In the population, especially among students, the average prevalence of use of smart drugs was $22.81 \%$, with a median of $12.65 \pm 25.06 \mathrm{SD}$.

The prevalence of the use of smart drugs is increasing [42-44]. Male sex is a risk factor for their use [39, 40, 45-47]. According to some studies, most students used smart drugs sporadically and without a doctor's prescription [42, 48]. Legal or illegal smart drugs were bought from friends, websites, or pharmacies. Some authors showed an increase in concentration from their studies and better memory [10, 42, 43, 49]. In some studies, students either did not believe in the neuroenhancement effect or had no effects from their use [50]. A strong individual variability in smart drug users has been hypothesized [51]. A lack of knowledge of the side effects and the possibility of abuse has emerged in many studies [39]. Many authors argue that there should be greater awareness about "smart drugs” through information campaigns [45]. In fact, Fond G. et al. [52], showed that the increased use of steroids as smart drugs raised a new public health problem, as corticoids can have serious side effects.

Table 2 (Ref. [10-12, 39-81]) highlights the main aspects of this systematic review.

\section{Discussion}

Smart drugs act on the cerebral cortex by modifying the concentrations of catecholamines, in particular, noradrenaline and dopamine. However, the pharmacodynamics are different for each individual drug (Fig. 2).

Caffeine is a common substance for cognitive improvement. Caffeine can be consumed through caffeinated drinks, energy drinks, or tablets [82]. Caffeine has three main mechanisms of action through which it improves alertness, attention and concentration: (i) inhibition of the activity of cyclic nucleotide phosphodiesterases and increase of Cyclic adenosine monophosphate (cAMP); (ii) blockade of adenosine receptors; (iii) mobilization of intracellular calcium [83-91].

Modafinil stimulates the noradrenergic system of the thalamus, of the frontal cortex, and of the hypothalamus. Modafinil stimulates the dopaminergic receptors of the accumbens, of the striatum, of the frontal cortex, and of the locus coeruleus [92]. This leads to an increase in the concentration of synaptic norepinephrine and dopamine [93, 94]. Amphetamine leads to an increased activation of central b-adrenoceptors [49]. Amphetamine is believed to act primarily through the dopaminergic system at the striatum and nucleus accumbens [95]. The risk of addiction to smart drugs is still debated [96]. Although many smart drugs work by increasing dopamine, there is no evidence of real addiction by abusers [97]. According to Swanson et al. [98] many students who used smart drugs were well aware of a possible addiction.

In fact, this systematic review of the literature shows that most people using smart drugs are unaware of potential addiction [11, 12, 39, 40, 44-50, 53-55]. In particular, a survey conducted among the teachers of a school included in this review showed that half of the teachers thought that smart drugs are useless and ineffective, while $40 \%$ thought smart drugs were addictive. Opinions on the side effects of smart drugs were different, and the teach- 


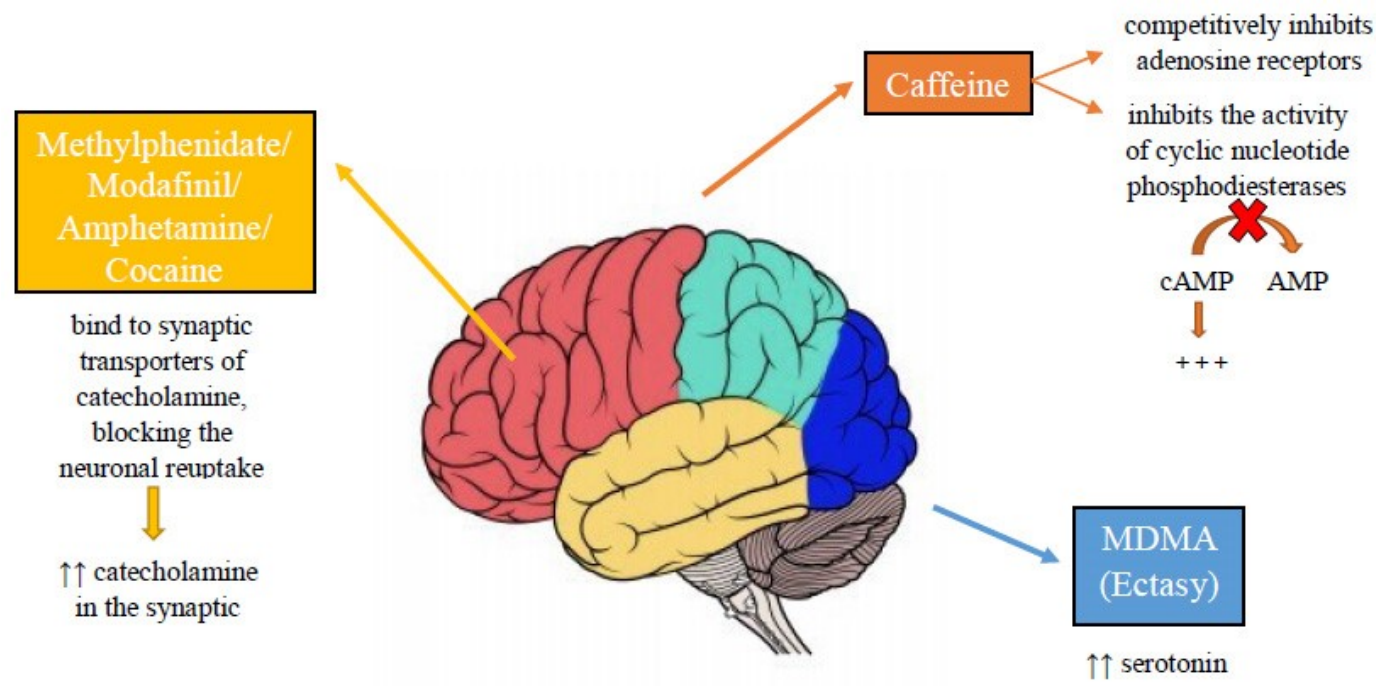

Fig. 2. Pharmacodynamics of the main smart drugs.

ers did not know them in depth [62]. Recent studies have reported an increase in the use of these drugs without a prescription in the last few years. Most of the students used performance-time enhancing drugs, and the main reasons were the following: improvement of cognitive functions, reduction of stress, increased free time, and increased school performance [97-103].

These results are consistent with the present systematic review that highlights that there was a dramatic increase in the use of smart drugs not only among students but also among workers (surgeons, teachers); most of the people taking smart drugs did not have a prescription. Finally, this study reiterates that the main reasons for the use of smart drugs were: improvement of cognitive functions, reduction of stress, increase in free time, and increase in school performance. Research on smart drugs is increasing. However, the real effectiveness of these drugs has not yet been fully investigated [104].

Several reasons lead to use of psychotropics. Sakakibara et al. [105] claimed that the effects of psychiatric drugs affect human sensitivity. Thus, certain moods can influence the effects of smart drugs. In addition, employees and students who confessed to using smart drugs to improve cognitive abilities often had a mental disorder, even if mild [106]. This would provide further evidence that neuroenhancement is used with self-medication for therapeutic and pain-relieving purposes [105, 106].

According to Lynch G et al. [92], methylphenidate (Ritalin) increased alertness. However, this seemed to occur more on simple tasks than on difficult ones. The same authors claimed that methylphenidate also increased working memory; however, the real effects were not fully investigated.

Cognitive enhancement of modafinil was also debated in the literature [86-91]. Randall et al. [107] claimed a marked improvement in attention in healthy human sub- jects, while Turner et al. [108] did not find these effects. As a result of these findings, cognitive enhancement was thought to be subjective, and modafinil did not result in overall cognitive enhancement. Beracochea et al. [109], however, showed that it increased concentration on the development of simple rules.

A meta-analysis [86] showed that for methylphenidate there was no evidence for neurological enhancement, although there was evidence for increased working memory. Modafinil had moderate effects on attention, although repeated doses only served to maintain wakefulness. Nicholson et al. [37] claimed that modafinil has a greater effect in people with a lower IQ. The same authors also argued that smart drugs increased self-confidence. Side effects were dizziness, insomnia and nervousness, as well as tachycardia. At high intraperitoneal doses (5-10 mg/kg) of methylphenidate in healthy rats there was an increase in locomotor activity and a decrease in cognitive activity. At lower doses $(0.25-1 \mathrm{mg} / \mathrm{kg})$ of methylphenidate in animal models, motor activity was not affected but there was an increase in cognitive activity $[2,110]$. This effect was due to an increase in dopamine and norepinephrine levels in the prefrontal cortex: at high doses dopamine binds to dopamine 2 (D2) receptors, while norepinephrine binds to $\alpha 1$ receptors with activation of neurons not involved in cognitive enhancement [111].

These results are consistent with those shown in this systematic review. Although the use/abuse of smart drugs is increasing, their real functioning is not yet fully understood [110-123]. One reason is that there are few experimental studies both on humans, which are limited to simple surveys, and on animal models. There are evident ethical problems with the experimentation of smart drugs on humans. However, it is crucial to increase experimental studies on animal models on the use of smart drugs to understand the real functioning of these molecules [124-131]. 


\begin{tabular}{|c|c|c|c|c|}
\hline Reference & Study design & Target & Type of smart drugs & Main findings \\
\hline Maier, L.J. [42] & Survey & 6275 students & $\begin{array}{l}\text { Methylphenidate (4.1\%), sedatives ( } 2.7 \%) \text {, } \\
\text { beta-blockers (1.2\%), alcohol (5.6\%), cannabis } \\
\text { (2.5\%), amphetamines ( } 0.4 \%) \text {, cocaine }(0.2 \%)\end{array}$ & $\begin{array}{l}\text { The reasons for smart drugs use was: increased learning (66.2\%), relaxation (51.2\%), stress } \\
\text { reduction (39.1\%), performance improvement (32.2\%), and curiosity (20\%). A significant } \\
\text { number of students experienced a learning improvement after smart drug use. Most students used } \\
\text { them sporadically before exams and not daily. }\end{array}$ \\
\hline Hupli, A. [43] & Survey & 113 students & $\begin{array}{l}\text { Not specified: legal and illegal drugs, and nutritional } \\
\text { supplements }\end{array}$ & $\begin{array}{l}\text { Of the 24/113 students interviewed admitted the use of cognitive enhancement drugs; only } 5 \\
\text { suffered from attention deficit hyperactivity disorder (ADHD) and used smart drugs with a } \\
\text { medical prescription, the others did not have a prescription. The reasons for using smart drugs } \\
\text { were: improved grades in school, increased creativity, increased concentration, streamlined study, } \\
\text { relaxing with friends, and better time management. } 18 \text { found positive effects, the others were } \\
\text { disappointed because they did not have these results. }\end{array}$ \\
\hline $\begin{array}{l}\text { Micoulaud- } \\
\text { Franchi, J. A [44] }\end{array}$ & Survey & 206 students & $\begin{array}{l}\text { Caffeine tablets, Methylphenidate, Amphetamines, } \\
\text { Modafinil, Piracetam }\end{array}$ & $\begin{array}{l}5.8 \% \text { of the students used illicit smart drugs to: improve academic performance, improve } \\
\text { concentration, and increase wakefulness in the sleep/wake ratio. } 16.7 \% \text { of all smart drugs users } \\
\text { employed smart drugs to cause euphoria or improve their mood. }\end{array}$ \\
\hline \multirow[t]{2}{*}{ Colucci, P. [49] } & $\begin{array}{l}\text { Experimental } \\
\text { study }\end{array}$ & Rats & Methylenedioxypyrovalerone & $\begin{array}{l}\text { A group of rats were given amphetamine and MDPV (individually or together) to evaluate } \\
\text { memory improvement. These two drugs act on the noradrenergic and dopaminergic systems. } \\
\text { These two molecules showed a memory improvement. }\end{array}$ \\
\hline & & & (MDPV), Amphetamine & \\
\hline Dubljević, V. [11] & Survey & $\begin{array}{l}11,000 \text { university } \\
\text { students }\end{array}$ & $\begin{array}{l}\text { Not specified: legal and illegal drugs, and nutritional } \\
\text { supplements }\end{array}$ & $\begin{array}{l}\text { Most college students who used smart drugs copied/falsified exams or otherwise cheated on } \\
\text { exams. }\end{array}$ \\
\hline Arria, A. M. [53] & $\begin{array}{l}\text { Longitudinal } \\
\text { prospective study }\end{array}$ & $\begin{array}{l}1253 \text { university } \\
\text { students }\end{array}$ & $\begin{array}{l}\text { Methylphenidate hydrochloride, Methylphenidate, } \\
\text { Dextroamphetamine, Methamphetamine, } \\
\text { Amphetamine, cannabis and alcohol }\end{array}$ & $\begin{array}{l}\text { Abuse of smart drugs in college students showed a positive association with the skipping of } \\
\text { classes and school commitments. }\end{array}$ \\
\hline Brand, R. [12] & Survey & 1438 students & $\begin{array}{l}\text { Not specified: legal and illegal drugs, and nutritional } \\
\text { supplements }\end{array}$ & $\begin{array}{c}\text { The reason for the use of smart drugs in students was divided into } 2 \text { types: "neuroenhancers" or } \\
\text { "fatigue-fighters". }\end{array}$ \\
\hline Pacifici, R. [45] & Survey & $\begin{array}{l}2621 \text { young adults } \\
\text { (14-35 years old) }\end{array}$ & $\begin{array}{l}\text { Not specified: legal and illegal drugs, anabolic } \\
\text { steroids, and nutritional supplements }\end{array}$ & $\begin{array}{l}\text { The main risk factors for using smart drugs were: male sex, bad family relationships, negative } \\
\text { influence of friends. The information and awareness campaign on these types of drugs should be } \\
\text { improved. }\end{array}$ \\
\hline Vargo, E.J. [10] & Survey & 13 students & $\begin{array}{l}\text { Modafinil, Methylphenidate hydrochloride, } \\
\text { Methylphenidate }\end{array}$ & $\begin{array}{l}\text { Modafinil was bought through friends or internet sites and the reason for its use was to catch up } \\
\text { on late exams and be in good standing with the university path. Most of the students reported an } \\
\text { improvement in work performance. }\end{array}$ \\
\hline Hildt, E. [46] & Survey & $\begin{array}{l}18 \text { university } \\
\text { students }\end{array}$ & $\begin{array}{l}\text { Modafinil, Methylphenidate hydrochloride, } \\
\text { Methylphenidate, Methamphetamine, Amphetamine }\end{array}$ & $\begin{array}{l}\text { From the analysis of the students' responses, smart drugs were not only used to improve school } \\
\text { performance, but also to create a balance between study and free time. The students wanted to } \\
\text { maximize their time and improve their memorization in order to have more free time. }\end{array}$ \\
\hline $\begin{array}{l}\text { Champagne, } \\
\text { [50] }\end{array}$ & Survey & $\begin{array}{l}420 \text { university } \\
\text { students }\end{array}$ & $\begin{array}{l}\text { Not specified: legal and illegal drugs, anabolic } \\
\text { steroids, and nutritional supplements }\end{array}$ & $\begin{array}{l}\text { The risk of using smart drugs was in students who believed in these drugs and their effects. Those } \\
\text { who did not believe in using smart drugs or thought it was wrong to use them had a lower risk of } \\
\text { abuse. }\end{array}$ \\
\hline Franke, A.G. [48] & Survey & $\begin{array}{l}1035 \text { university } \\
\text { students }\end{array}$ & $\begin{array}{l}\text { Not specified: legal and illegal drugs, anabolic } \\
\text { steroids, and nutritional supplements }\end{array}$ & $\begin{array}{l}\text { The prevalence of smart drug abuse was higher than people thought. Most consumers did not } \\
\text { have a prescription. }\end{array}$ \\
\hline
\end{tabular}




\begin{tabular}{|c|c|c|c|c|}
\hline \multirow[b]{2}{*}{ Reference } & & & & \\
\hline & Study design & Target & Type of smart drugs & Main findings \\
\hline Stoeber, J [54] & Survey & 272 university students & $\begin{array}{l}\text { Not specified: legal and illegal drugs, anabolic } \\
\text { steroids, and nutritional supplements }\end{array}$ & There was an increase in the prevalence of the use of smart drugs. \\
\hline Dietz, P. [55] & Survey & 1021 university students & $\begin{array}{l}\text { Not specified: legal and illegal drugs, anabolic } \\
\text { steroids, and nutritional supplements }\end{array}$ & $\begin{array}{l}\text { One-time use of smart drugs was found in } 88 \% \text { of students, the reasons were: improved mood, } \\
\text { improved cognitive performance, curiosity, and decreased stress. Only } 19 \% \text { had a prescription for } \\
\text { their use. }\end{array}$ \\
\hline Franke, A.G. [39] & Survey & 255 teachers of schools & $\begin{array}{l}\text { Not specified: legal and illegal drugs, anabolic } \\
\text { steroids, and nutritional supplements }\end{array}$ & $\begin{array}{l}\text { 73.3\% of teachers knew about smart drugs, mainly thanks to TV, Internet, and through students. } \\
\text { Half of the teachers thought that smart drugs were useless and ineffective. } 40 \% \text { thought smart } \\
\text { drugs were addictive. Opinions on the side effects of smart drugs were different and the teachers } \\
\text { did not know them in depth. }\end{array}$ \\
\hline Franke, A.G. [40] & Survey & 1145 surgeons & $\begin{array}{l}\text { Not specified: legal and illegal drugs, anabolic } \\
\text { steroids, and nutritional supplements }\end{array}$ & $\begin{array}{l}\text { 9\% of surgeons used smart drugs, even illicit ones, at least once in their life. The reason for taking } \\
\text { these drugs was: increased concentration, trying to reduce stress, high workload, and reducing } \\
\text { fatigue. Coping strategies should be part of physicians’ training programs. }\end{array}$ \\
\hline Deline, S. [47] & Survey & 5967 people & $\begin{array}{l}\text { Not specified: legal and illegal drugs, anabolic } \\
\text { steroids, and nutritional supplements }\end{array}$ & $\begin{array}{l}\text { The most frequent effect was the reduction of anxiety or stress (80\%). Most people thought they } \\
\text { had an increase in memory, concentration, and increased wakefulness. }\end{array}$ \\
\hline $\begin{array}{l}\text { Van Der Schaaf, } \\
\text { M.E. [51] }\end{array}$ & $\begin{array}{l}\text { Cross-over } \\
\text { study }\end{array}$ & 19 students & Methylphenidate & $\begin{array}{l}\text { Methylphenidate improved learning in students with high working memory. However, the effect } \\
\text { was found to have strong individual variability on cognitive enhancement. }\end{array}$ \\
\hline $\begin{array}{l}\text { McDermott, } \mathrm{H} . \\
{[56]}\end{array}$ & Survey & 506 university students & $\begin{array}{l}\text { Not specified: legal and illegal drugs, anabolic } \\
\text { steroids, and nutritional supplements }\end{array}$ & $\begin{array}{l}\text { Half of the students reported using smart drugs for recreational purposes, } 20 \% \text { said they used } \\
\text { them as cognitive enhancers. Use was more common among males than females. The most } \\
\text { frequent reasons for the use of smart drugs were: improving concentration, staying awake, and } \\
\text { meeting the demands of the courses. }\end{array}$ \\
\hline Steward, A [57] & Survey & 15 university students & Modafinil & $\begin{array}{l}\text { The reason was to improve academic performance, improve concentration, increase wakefulness } \\
\text { in the sleep/wake ratio. }\end{array}$ \\
\hline Mousavi, F. [58] & Survey & 579 students & Modafinil, Methylphenidate, Amphetamine & The use of smart drugs improved cognitive performance. \\
\hline Javed, N. [59] & Survey & 400 students & Methylphenidate & $\begin{array}{l}\text { The reason was to improve academic performance, improve concentration, and increase } \\
\text { wakefulness in the sleep/wake ratio. }\end{array}$ \\
\hline De Bruyn, S. [60] & Survey & 3159 university students & Modafinil, Methylphenidate, Amphetamine & $8.7 \%$ of students used smart drugs to improve concentration. \\
\hline $\begin{array}{l}\text { London-Nadeau, } \\
\text { K. [61] }\end{array}$ & Survey & 433 university students & Modafinil, Methylphenidate, Amphetamine, Caffeine & $74.7 \%$ of students used smarts drugs to improve academic performance. \\
\hline Pighi, M. [62] & Survey & 33-77 university students & Modafinil, Methylphenidate, Amphetamine & $5 / 30 \%$ of students used smart drugs to improve concentration. \\
\hline Fallah, G. [63] & Survey & 560 university students & Methylphenidate, Amphetamine & 79.3\% of students used smart drugs to improve academic performance. \\
\hline Maier, L.J. [64] & Survey & 109,398 students & $\begin{array}{l}\text { Not specified: legal and illegal drugs, anabolic } \\
\text { steroids, and nutritional supplements }\end{array}$ & $\begin{array}{l}\text { The reason was to improve academic performance, improve concentration, and increase } \\
\text { wakefulness in the sleep/wake ratio. }\end{array}$ \\
\hline Lucke, J. [65] & Survey & 1136 students & $\begin{array}{l}\text { Not specified: legal and illegal drugs, anabolic } \\
\text { steroids, and nutritional supplements }\end{array}$ & $6.5 \%$ of students used smart drugs to improve academic performance. \\
\hline Riddell, C. [66] & Survey & 642 university students & Modafinil, Methylphenidate, Amphetamine & $6.32 \%$ of students used smart drugs to improve academic performance. \\
\hline
\end{tabular}


Table 2. Continued.

\begin{tabular}{|c|c|c|c|c|}
\hline Reference & Study design & Target & Type of smart drugs & Main findings \\
\hline Papazisis, G. [67] & Survey & 591 university students & $\begin{array}{l}\text { Not specified: legal and illegal drugs, anabolic steroids, } \\
\text { and nutritional supplements }\end{array}$ & $10 / 25 \%$ of students used smart drugs to improve academic performance. \\
\hline Ram, S. [68] & Survey & 449 university students & Modafinil, Methylphenidate, Amphetamine & $\begin{array}{l}\text { The reason was to improve academic performance, improve concentration, and increase } \\
\text { wakefulness in the sleep/wake ratio. }\end{array}$ \\
\hline Lazuras, L. [69] & Survey & 450 university students & Modafinil, Methylphenidate & $\begin{array}{l}\text { The reason was to improve academic performance, improve concentration, and increase } \\
\text { wakefulness in the sleep/wake ratio. }\end{array}$ \\
\hline Jain, R. [70] & Survey & 541 university students & Methylphenidate & $11 \%$ of students used smart drugs to improve academic performance. \\
\hline Vagwala, M.K. [71] & Survey & 66 university students & Modafinil, Methylphenidate, Amphetamine & $\begin{array}{l}\text { The reason was to improve academic performance, improve concentration, and increase } \\
\text { wakefulness in the sleep/wake ratio. }\end{array}$ \\
\hline Jensen, C. [72] & Survey & 38 university students & Modafinil, Methylphenidate, Amphetamine & $\begin{array}{l}\text { The reason was to improve academic performance, improve concentration, and increase } \\
\text { wakefulness in the sleep/wake ratio. }\end{array}$ \\
\hline $\begin{array}{l}\text { Gudmundsdottir, B.G. } \\
\text { [73] }\end{array}$ & Survey & 521 university students & $\begin{array}{l}\text { Not specified: legal and illegal drugs, anabolic steroids, } \\
\text { and nutritional supplements }\end{array}$ & $11 \%$ of students used smart drugs to improve academic performance. \\
\hline Fond, G. [52] & Survey & 1718 university students & Modafinil, Methylphenidate, Amphetamine & Of students used smart drugs to improve academic performance. \\
\hline Lengvenyt' e [74] & Survey & 579 university students & Modafinil, Methylphenidate, Amphetamine & $33 \%$ of students used smart drugs to improve academic performance. \\
\hline Emanuel, R.M. [75] & Survey & 18 university students & Modafinil, Methylphenidate, Amphetamine, Piracetam & $5.8 \%$ of students used smart drugs to improve academic performance. \\
\hline $\begin{array}{l}\text { de Oliveira C. P. B. } \\
\text { [76] }\end{array}$ & Survey & 1865 university students & Modafinil, Methylphenidate, Piracetam & $\begin{array}{l}\text { The most frequent reason for consumption of smart drugs was due to the increase cognitive } \\
\text { performance. Most of the students obtained these substances from a friend. The prevalence } \\
\text { of users was } 22 \% \text {. }\end{array}$ \\
\hline Maier L. J. [77] & Survey & 3056 university students & Modafinil, Methylphenidate & $\begin{array}{l}\text { The most frequent reason for consumption of smart drugs was due to the increase cognitive } \\
\text { performance. The prevalence of users was } 14.3 \% .\end{array}$ \\
\hline Singh I. [41] & Survey & 877 university students & $\begin{array}{l}\text { Not specified: legal and illegal drugs, anabolic steroids, } \\
\text { and nutritional supplements }\end{array}$ & $\begin{array}{l}\text { The reason was to improve academic performance, improve concentration, and increase } \\
\text { wakefulness in the sleep/wake ratio. The prevalence of users was } 2 \% \text {. }\end{array}$ \\
\hline Cândido R. C. F. [78] & Survey & 438 university students & Methylphenidate & $\begin{array}{l}\text { The reason was to improve academic performance, improve concentration, and increase } \\
\text { wakefulness in the sleep/wake ratio. The prevalence of users was } 5.8 \% \text {. }\end{array}$ \\
\hline Dietz P. [79] & Survey & 2284 students & Caffeine pills & $\begin{array}{l}\text { The reason was to improve academic performance, improve concentration, and increase } \\
\text { wakefulness in the sleep/wake ratio. The prevalence of users was } 15 \% \text {. }\end{array}$ \\
\hline Schelle K. J. [80] & Survey & 1572 students & $\begin{array}{l}\text { Not specified: legal and illegal drugs, anabolic steroids, } \\
\text { and nutritional supplements }\end{array}$ & $\begin{array}{l}\text { The reason was to improve academic performance, improve concentration, and increase } \\
\text { wakefulness in the sleep/wake ratio. }\end{array}$ \\
\hline $\begin{array}{l}\text { Rubin-Kahana D.S. } \\
\text { [81] }\end{array}$ & Survey & 1453 students & Amphetamines, and Modafinil & $\begin{array}{l}\text { Almost half of the users (47.1\%) acquired the drug with a prescription, but without a } \\
\text { diagnosis of a related medical disorder. Factors found to impact include: fear of failing the } \\
\text { exam, self-reports of being a competitive person. }\end{array}$ \\
\hline Fond G. [52] & Survey & $\begin{array}{l}1718 \text { students and } \\
\text { physicians }\end{array}$ & Methylphenidate, Modafinil, and Steroids & $\begin{array}{l}\text { Lifetime prevalence of psychostimulant use was } 33 \% \text {. The consumption mainly aimed at } \\
\text { increasing academic performance and wakefulness during competitive exams preparation. } \\
\text { Corticoids were the most frequently consumed before methylphenidate and modafinil. }\end{array}$ \\
\hline
\end{tabular}


However, peripheral and central mechanisms are involved in the development of memory for an event. Although these mechanisms are not yet known, hormones are known to affect memory primarily through plasma levels of steroids, adrenaline, and glucose. Piracetam seems to work by affecting peripheral steroid levels. Instead, amphetamines, methylphenidate (Ritalin), antidepressants, and anxiolytics seem to act directly centrally by reducing anxiety, improving attention [132-134]. Instead, methylphenidate acts by increasing the levels of extracellular catecholamines (adrenaline and noradrenaline), contributing to a strengthening of memory [51]. Caffeine also appears to affect memory and ability to learn. In fact, a study conducted on 48 individuals, moderate consumers of caffeine-based beverages, showed, both at a behavioral and neuroanatomical level, a correlation between caffeine intake and greater short-term memory efficiency [135].

It is of crucial importance to regulate the use of smart drugs, to inform the community about safety, efficacy and social consequences, mainly when they are not prescribed. In addition, the community should be informed about alternative cognitive enhancement pathways such as regular rest, meditation and physical activity. Finally, the development of a legal market for smart drugs should be encouraged in order to counteract the black market that trades drugs of poor quality and purity [90, 136].

Some authors report ethical problems regarding the consumption of smart drugs: is it ethical to use them to improve cognitive functions? Is it ethical to take these drugs to gain an advantage? The answer is debated from an ethical and social point of view. They should be banned because they create an "unnatural" advantage (such as doping in sport). However, according to other authors, their increased use among students is inevitable, as school and university are competitive, and the ban implies the use of illegal ways to obtain these products. Finally, their consumption is expected to be even higher in the future $[137,138]$. Adverse events, especially long-term, are only partially known: methylphenidate is associated with drug addiction and suicide attempts. Modafinil, on the other hand, is related to psychiatric disorders, increased cardiovascular risk, and severe allergic reactions $[37,139]$. These aspects are of great interest to the population and to public safety/health considering the high use/abuse of smart drugs. The increase in competitiveness among school and university students, the increasingly demanding work, will inevitably lead to an increase in the abuse of smart drugs without in-depth knowledge.

A recent systematic review [140] of the literature was based solely on the use of drugs among school and university students. Although most of the people who use smart drugs are students, the present study is not limited to university students alone but also to the knowledge/use among teachers; surgeons were also evaluated [46, 50].

This systematic review focused on and showed an important general picture of the prevalence of smart drug use, and on potential academic or work performance. Future research on this topic needs to be encouraged, establishing more precisely why cognitive enhancement is subjective and the effective dosage to achieve it. Furthermore, this systematic review revealed an imbalance between the use of smart drugs among students and the ignorance of educators on the subject (teachers, family). Thus, it is important that information and awareness campaigns aimed at both young adults and parents begin.

\section{Conclusions}

The knowledge of the effects of smart drugs is still not fully understood; this systematic review highlights how the beneficial and collateral effects are still unclear. There are conflicting opinions; in fact, as regards their actual functioning and benefit, it is not known whether the benefits reported by consumers are due to drugs, the placebo effect or a combination of these. Literature studies have shown a growing prevalence among university and school students. The reasons were: improvement in concentration, performance, time optimization, and increase of free time. The real prevalence is underestimated: it is important for the scientific community to focus on this issue with more studies on animal models to validate their effectiveness. In fact, most of the studies analyzed were surveys with few experimental studies, even if this was due to ethical problems. Television campaigns to raise awareness among families and children are also important.

\section{Author contributions}

Conceptualization, ME, GC, FM, FS and MS; methodology, ME, GC, FM, GLR, NDN, GM, FS and MS; validation, ME, GC, FM, GLR, NDN, GM, FS and MS; formal analysis, ME, GC, FM, FS and MS; writing-original draft preparation, ME, GC, FM, FS and MS; writingreview and editing, ME, GC, FM, GLR, NDN, GM, FS and MS. All authors have read and agreed to the published version of the manuscript.

\section{Ethics approval and consent to participate}

Not applicable.

\section{Acknowledgment}

We wish to thank the Scientific Bureau of the University of Catania for language support.

\section{Funding}

This research received no external funding. 


\section{Conflict of interest}

The authors declare no conflict of interest.

\section{References}

[1] Lanni C, Lenzken SC, Pascale A, Del Vecchio I, Racchi M, Pistoia $\mathrm{F}$, et al. Cognition enhancers between treating and doping the mind. Pharmacological Research. 2008; 57: 196-213.

[2] Frati P, Kyriakou C, Del Rio A, Marinelli E, Vergallo GM, Zaami $\mathrm{S}$, et al. Smart drugs and synthetic androgens for cognitive and physical enhancement: revolving doors of cosmetic neurology. Current Neuropharmacology. 2015; 13: 5-11.

[3] Rose SPR. 'Smart drugs': do they work? Are they ethical? Will they be legal? Nature Reviews Neuroscience. 2002; 3: 975-979.

[4] Farah MJ, Illes J, Cook-Deegan R, Gardner H, Kandel E, King $\mathrm{P}$, et al. Neurocognitive enhancement: what can we do and what should we do? Nature Reviews Neuroscience. 2004; 5: 421425.

[5] Chatterjee A. The promise and predicament of cosmetic neurology. Journal of Medical Ethics. 2006; 32: 110-113.

[6] Normann C, Berger M. Neuroenhancement: status quo and perspectives. European Archives of Psychiatry and Clinical Neuroscience. 2008; 258: 110-114.

[7] Scheske C, Schnall S. The Ethics of "Smart Drugs": Moral Judgments about Healthy People's Use of Cognitive-Enhancing Drugs. Basic and Applied Social Psychology. 2012; 34: 508515.

[8] Sahakian BJ, Bruhl AB, Cook J, Killikelly C, Savulich G, Piercy $\mathrm{T}$, et al. The impact of neuroscience on society: cognitive enhancement in neuropsychiatric disorders and in healthy people. Philosophical Transactions of the Royal Society B: Biological Sciences. 2015; 370: 20140214.

[9] Wilens TE, Adler LA, Adams J, Sgambati S, Rotrosen J, Sawtelle R, et al. Misuse and diversion of stimulants prescribed for ADHD: a systematic review of the literature. Journal of the American Academy of Child and Adolescent Psychiatry. 2008; 47: 21-31.

[10] Vargo E J, Petróczi A. “It was me on a good day”: exploring the smart drug use phenomenon in England. Frontiers in Psychology. 2016; 7: 779.

[11] Esposito M, Licciardello G, Privitera F, Iannuzzi S, Liberto A, Sessa F, et al. Forensic Post-Mortem Investigation in AAS Abusers: Investigative Diagnostic Protocol. A Systematic Review. Diagnostics. 2021; 11: 1307.

[12] Sessa F, Esposito M, Messina G, Di Mizio G, Di Nunno N, Salerno M. Sudden Death in Adults: A Practical Flow Chart for Pathologist Guidance. Healthcare. 2021; 9:870.

[13] Fone KC, Nutt DJ. Stimulants: use and abuse in the treatment of attention deficit hyperactivity disorder. Current Opinion in Pharmacology. 2005; 5: 87-93.

[14] Fry JM. Treatment modalities for narcolepsy. Neurology. 1998; 50: S43-S48.

[15] Dell'Osso B, Dobrea C, Cremaschi L, Arici C, Altamura AC. Wake-promoting pharmacotherapy for psychiatric disorders. Current Psychiatry Reports. 2014; 16: 524.

[16] Rammohan KW, Rosenberg JH, Lynn DJ, Blumenfeld AM, Pollak CP, Nagaraja HN. Efficacy and safety of modafinil (Provigil) for the treatment of fatigue in multiple sclerosis: a two centre phase 2 study. Journal of Neurology, Neurosurgery, and Psychiatry. 2002; 72: 179-183.

[17] Dackis CA, Kampman KM, Lynch KG, Pettinati HM, O’Brien CP. A double-blind, placebo-controlled trial of modafinil for cocaine dependence. Neuropsychopharmacology. 2005; 30: 205211.

[18] Ilieva IP, Hook CJ, Farah MJ. Prescription Stimulants’ Effects on Healthy Inhibitory Control, Working Memory, and Episodic Memory: a Meta-analysis. Journal of Cognitive Neuroscience. 2015; 27: 1069-1089.
[19] Docherty JR. Pharmacology of stimulants prohibited by the World Anti-Doping Agency (WADA). British Journal of Pharmacology. 2008; 154: 606-622.

[20] Phillips JB, Simmons RG, Arnold RD. A single dose of armodafinil significantly promotes vigilance 11 hours post-dose. Military Medicine. 2011; 176: 833-839.

[21] Grinspoon L, Bakalar JB. The use of cannabis as a mood stabilizer in bipolar disorder: anecdotal evidence and the need for clinical research. Journal of Psychoactive Drugs. 1998; 30: 171177.

[22] Bambico FR, Katz N, Debonnel G, Gobbi G. Cannabinoids Elicit Antidepressant-Like Behavior and Activate Serotonergic Neurons through the Medial Prefrontal Cortex. Journal of Neuroscience. 2007; 27: 11700-11711.

[23] Cao C, Li Y, Liu H, Bai G, Mayl J, Lin X, et al. The Potential Therapeutic Effects of THC on Alzheimer's Disease. Journal of Alzheimer's Disease. 2014; 42: 973-984.

[24] Kreitzer AC, Malenka RC. Endocannabinoid-mediated rescue of striatal LTD and motor deficits in Parkinson's disease models. Nature. 2007; 445: 643-647.

[25] Sandyk R, Awerbuch G. Marijuana and Tourette's syndrome. Journal of Clinical Psychopharmacology. 1988; 8: 444-445.

[26] Cerretani D, Bello S, Cantatore S, Fiaschi AI, Montefrancesco G, Neri M, et al. Acute administration of 3,4methylenedioxymethamphetamine (MDMA) induces oxidative stress, lipoperoxidation and $\mathrm{TNF} \alpha$-mediated apoptosis in rat liver. Pharmacological Research. 2011; 64: 517-527.

[27] Pomara C, D’Errico S, Zummo L, Cappello F, Li Volti G. MDMA Administration and Heat Shock Proteins Response: Foreseeing a Molecular Link. Current Pharmaceutical Biotechnology. 2010; 11: 496-499.

[28] Riezzo I, Cerretani D, Fiore C, Bello S, Centini F, D’Errico S, et al. Enzymatic-nonenzymatic cellular antioxidant defense systems response and immunohistochemical detection of MDMA, VMAT2, HSP70, and apoptosis as biomarkers for MDMA (Ecstasy) neurotoxicity. Journal of Neuroscience Research. 2010; 88: 905-916.

[29] Cerretani D, Riezzo I, Fiaschi AI, Centini F, Giorgi G, D’Errico $\mathrm{S}$, et al. Cardiac oxidative stress determination and myocardial morphology after a single ecstasy (MDMA) administration in a rat model. International Journal of Legal Medicine. 2008; 122: 461-469.

[30] Baggott MJ, Coyle JR, Siegrist JD, Garrison KJ, Galloway GP, Mendelson JE. Effects of 3,4methylenedioxymethamphetamine on socioemotional feelings, authenticity, and autobiographical disclosure in healthy volunteers in a controlled setting. Journal of Psychopharmacology. 2016; 30: 378-387.

[31] Sessa B, Nutt D. Making a medicine out of MDMA. British Journal of Psychiatry. 2015; 206: 4-6.

[32] Sessa B. Why MDMA therapy for alcohol use disorder? And why now? Neuropharmacology. 2018; 142: 83-88.

[33] Zimmerman JL. Cocaine intoxication. Critical Care Clinics. 2012; 28: 517-526.

[34] Donroe JH, Tetrault JM. Substance Use, Intoxication, and Withdrawal in the Critical Care Setting. Critical Care Clinics. 2017; 33: $543-558$

[35] Sin B, Ternas T, Motov SM. The Use of Subdissociative-dose Ketamine for Acute Pain in the Emergency Department. Academic Emergency Medicine. 2015; 22: 251-257.

[36] Page MJ, McKenzie JE, Bossuyt PM, Boutron I, et al. The PRISMA 2020 statement: an updated guideline for reporting systematic reviews. British Medical Journal. 2021; 372: 71.

[37] Nicholson PJ, Wilson N. Smart drugs: implications for general practice. British Journal of General Practice. 2017; 67: 100-101.

[38] Woźniak-Karczewska M, Čvančarová M, Chrzanowski Ł, Corvini PF, Cichocka D. Bacterial isolates degrading ritalinic acid-human metabolite of neuro enhancer methylphenidate. New Biotechnology. 2018; 43: 30-36.

[39] Franke AG, Lehmberg S, Soyka M. Pharmacological Neuroenhancement: teachers' knowledge and attitudes-Results from a survey study among teachers in Germany. Substance Abuse 
Treatment, Prevention, and Policy. 2016; 11: 32.

[40] Franke AG, Bagusat C, Dietz P, Hoffmann I, Simon P, Ulrich R, et al. Use of illicit and prescription drugs for cognitive or mood enhancement among surgeons. BMC Medicine. 2013; 11: 102.

[41] Singh I, Bard I, Jackson J. Robust resilience and substantial interest: a survey of pharmacological cognitive enhancement among university students in the UK and Ireland. PLoS ONE. 2014; 9: e105969.

[42] Maier LJ, Liechti ME, Herzig F, Schaub MP. To dope or not to dope: neuroenhancement with prescription drugs and drugs of abuse among Swiss university students. PLoS ONE. 2013; 8: e77967.

[43] Hupli A, Didžiokaitė G, Ydema M. Toward the smarter use of smart drugs: Perceptions and experiences of university students in the Netherlands and Lithuania. Contemporary Drug Problems. 2016; 43: 242-257.

[44] Micoulaud-Franchi J, MacGregor A, Fond G. A preliminary study on cognitive enhancer consumption behaviors and motives of French Medicine and Pharmacology students. European Review for Medical and Pharmacological Sciences. 2014; 18: 1875-1878.

[45] Pacifici R, Palmi I, Vian P, Andreotti A, Mortali C, Berretta P, et al. Emerging trends in consuming behaviours for non-controlled substances by Italian urban youth: a cross sectional study. Annali dell'Istituto Superiore di Sanita. 2016; 52: 104-113.

[46] Hildt E, Lieb K, Franke AG. Life context of pharmacological academic performance enhancement among university students—a qualitative approach. BMC Medical Ethics. 2014; 15: 23.

[47] Deline S, Baggio S, Studer J, N’Goran AA, Dupuis M, Henchoz $\mathrm{Y}$, et al. Use of neuroenhancement drugs: prevalence, frequency and use expectations in Switzerland. International Journal of Environmental Research and Public Health. 2014; 11: 3032-3045.

[48] Franke AG, Bonertz C, Christmann M, Huss M, Fellgiebel A, Hildt E, et al. Non-medical use of prescription stimulants and illicit use of stimulants for cognitive enhancement in pupils and students in Germany. Pharmacopsychiatry. 2011; 44: 60-66.

[49] Colucci P, Mancini GF, Santori A, Zwergel C, Mai A, Trezza V, et al. Amphetamine and the smart drug 3,4methylenedioxypyrovalerone (MDPV) induce generalization of fear memory in rats. Frontiers in Molecular Neuroscience. 2019; 12: 292.

[50] Champagne J, Gardner B, Dommett EJ. Modelling predictors of UK undergraduates' attitudes towards smart drugs. Trends in Neuroscience and Education. 2019; 14: 33-39.

[51] van der Schaaf ME, Fallon SJ, Ter Huurne N, Buitelaar J, Cools R. Working memory capacity predicts effects of methylphenidate on reversal learning. Neuropsychopharmacology. 2013; 38: 2011-2018.

[52] Fond G, Gavaret M, Vidal C, Brunel L, Riveline J, MicoulaudFranchi J, et al. (Mis)use of Prescribed Stimulants in the Medical Student Community: Motives and Behaviors: a PopulationBased Cross-Sectional Study. Medicine. 2016; 95: e3366.

[53] Arria AM, Wilcox HC, Caldeira KM, Vincent KB, GarnierDykstra LM, O'Grady KE. Dispelling the myth of "smart drugs": Cannabis and alcohol use problems predict nonmedical use of prescription stimulants for studying. Addictive Behaviors. 2013; 38: 1643-1650.

[54] Stoeber J, Hotham S. Perfectionism and attitudes toward cognitive enhancers (“smart drugs"). Personality and Individual Differences. 2016; 88: 170-174.

[55] Dietz P, Soyka M, Franke AG. Pharmacological Neuroenhancement in the Field of Economics-Poll Results from an Online Survey. Frontiers in Psychology. 2016; 7: 520.

[56] McDermott H, Lane H, Alonso M. Working smart: the use of 'cognitive enhancers' by UK university students. Journal of Further and Higher Education. 2021; 45: 270-283.

[57] Steward A, Pickersgill M. Developing expertise, customising sleep, enhancing study practices: exploring the legitimisation of modafinil use within the accounts of UK undergraduate students. Drugs: Education, Prevention and Policy. 2019; 26: 347-355.

[58] Mousavi F, Shojaei P, Markeh H P. The Use of Cognitive En- hancers Among Medical Students. International Journal of High Risk Behaviors and Addiction. 2019; 8: e92377.

[59] Javed N, Ahmed F, Saeed S, Amir R, Khan H, Iqbal SP. Prevalence of Methylphenidate Misuse in Medical Colleges in Pakistan: a Cross-sectional Study. Cureus. 2019; 11: e5879.

[60] De Bruyn S, Wouters E, Ponnet K, Van Hal G. Popping smart pills in medical school: are competition and stress associated with the misuse of prescription stimulants among students? Substance Use \& Misuse. 2019; 54: 1191-1202.

[61] London-Nadeau K, Chan P, Wood S. Building Conceptions of Cognitive Enhancement: University Students' Views on the Effects of Pharmacological Cognitive Enhancers. Substance Use \& Misuse. 2019; 54: 908-920.

[62] Pighi M, Pontoni G, Sinisi A, Ferrari S, Mattei G, Pingani L, et al. Use and Propensity to Use Substances as Cognitive Enhancers in Italian Medical Students. Brain Sciences. 2018; 8: 197.

[63] Fallah G, Moudi S, Hamidia A, Bijani A. Stimulant use in medical students and residents requires more careful attention. Caspian Journal of Internal Medicine. 2018; 9: 87-91.

[64] Maier LJ, Ferris JA, Winstock AR. Pharmacological cognitive enhancement among non-ADHD individuals-a cross-sectional study in 15 countries. International Journal on Drug Policy. 2018; 58: 104-112.

[65] Lucke J, Jensen C, Dunn M, Chan G, Forlini C, Kaye S, et al. Non-medical prescription stimulant use to improve academic performance among Australian university students: prevalence and correlates of use. BMC Public Health. 2018; 18: 1270.

[66] Riddell C, Jensen C, Carter O. Cognitive Enhancement and Coping in an Australian University Student Sample. Journal of Cognitive Enhancement. 2018; 2: 63-69.

[67] Papazisis G, Tsakiridis I, Siafis S. Nonmedical Use of Prescription Drugs among Medical Students and the Relationship with Illicit Drug, Tobacco, and Alcohol Use. Substance Abuse. 2019; 12: 1178221818802298.

[68] Ram SS, Hussainy S, Henning M, Stewart K, Jensen M, Russell B. Attitudes toward Cognitive Enhancer Use among New Zealand Tertiary Students. Substance Use and Misuse. 2017; 52: 1387-1392.

[69] Lazuras L, Ypsilanti A, Lamprou E, Kontogiorgis C. Pharmaceutical Cognitive Enhancement in Greek University Students Differences between Users and Non-Users in Social Cognitive Variables, Burnout, and Engagement. Substance Use and Misuse. 2017; 52: 950-958.

[70] Jain R, Chang CC, Koto M, Geldenhuys A, Nichol R, Joubert G. Non-medical use of methylphenidate among medical students of the University of the Free State. South African Journal of Psychology. 2017; 23: 1006.

[71] Vagwala MK, Bicquelet A, Didziokaite G, Coomber R, Corrigan O, Singh I. Towards a Moral Ecology of Pharmacological Cognitive Enhancement in British Universities. Neuroethics. 2017; 10: 389-403.

[72] Jensen C, Forlini C, Partridge B, Hall W. Australian university students' coping strategies and use of pharmaceutical stimulants as cognitive enhancers. Frontiers in Psychology. 2016; 7: 277.

[73] Gudmundsdottir BG, Weyandt L, Ernudottir GB. Prescription Stimulant Misuse and ADHD Symptomatology among College Students in Iceland. Journal of Attention Disorders. 2020; 24: 384-401.

[74] Lengvenytė A, Strumila R. Do medical students use cognitive enhancers to study? Prevalence and correlates from lithuanian medical students sample. European Psychiatry. 2016; 33: S304S304.

[75] Emanuel RM, Frellsen SL, Kashima KJ, Sanguino SM, Sierles FS, Lazarus CJ. Cognitive enhancement drug use among future physicians: findings from a multi-institutional census of medical students. Journal of General Internal Medicine. 2013; 28: 10281034.

[76] de Oliveira Cata Preta B, Miranda VIA, Bertoldi AD. Psychostimulant Use for Neuroenhancement (Smart Drugs) among College Students in Brazil. Substance Use \& Misuse. 2020; 55: 613-621. 
[77] Maier LJ, Liakoni E, Schildmann J, Schaub MP, Liechti ME. Swiss University Students’ Attitudes toward Pharmacological Cognitive Enhancement. PLoS ONE. 2015; 10: e0144402.

[78] Cândido RCF, Perini E, Pádua CMD, Junqueira DR. Prevalence of and factors associated with the use of methylphenidate for cognitive enhancement among university students. Einstein. 2019; 18: eAO4745.

[79] Dietz P, Iberl B, Schuett E, van Poppel M, Ulrich R, Sattler MC. Prevalence Estimates for Pharmacological Neuroenhancement in Austrian University Students: its Relation to Health-Related Risk Attitude and the Framing Effect of Caffeine Tablets. Frontiers in Pharmacology. 2018; 9: 494.

[80] Schelle KJ, Olthof BMJ, Reintjes W, Bundt C, Gusman-Vermeer J, van Mil ACCM. A survey of substance use for cognitive enhancement by university students in the Netherlands. Frontiers in Systems Neuroscience. 2015; 9: 10.

[81] Rubin-Kahana DS, Rubin-Kahana Z, Kuperberg M, Stryjer R, Yodashkin-Porat D. Cognitive enhancement drug use among resident physicians: Prevalence and motivations for useresults from a survey. Journal of Addictive Diseases. 2020; 38: 250-256.

[82] Franke AG, Bagusat C, Rust S, Engel A, Lieb K. Substances used and prevalence rates of pharmacological cognitive enhancement among healthy subjects. European Archives of Psychiatry and Clinical Neuroscience. 2014; 264: S83-S90.

[83] Arnsten AFT. Toward a New Understanding of Attention-Deficit Hyperactivity Disorder Pathophysiology. CNS Drugs. 2009; 23 : 33-41.

[84] Maier LJ, Wunderli MD, Vonmoos M, Römmelt AT, Baumgartner MR, Seifritz E, et al. Pharmacological cognitive enhancement in healthy individuals: a compensation for cognitive deficits or a question of personality? PLoS ONE. 2015; 10: e0129805.

[85] Fond G, Micoulaud-Franchi J, Brunel L, Macgregor A, Miot S, Lopez R, et al. Innovative mechanisms of action for pharmaceutical cognitive enhancement: a systematic review. Psychiatry Research. 2015; 229: 12-20.

[86] Mereu M, Bonci A, Newman AH, Tanda G. The neurobiology of modafinil as an enhancer of cognitive performance and a potential treatment for substance use disorders. Psychopharmacology. 2013; 229: 415-434.

[87] Repantis D, Schlattmann P, Laisney O, Heuser I. Modafinil and methylphenidate for neuroenhancement in healthy individuals: a systematic review. Pharmacological Research. 2010; 62: 187206

[88] Sahakian BJ, Morein-Zamir S. Neuroethical issues in cognitive enhancement. Journal of Psychopharmacology. 2011; 25: 197 204.

[89] Urban KR, Gao W. Performance enhancement at the cost of potential brain plasticity: neural ramifications of nootropic drugs in the healthy developing brain. Frontiers in Systems Neuroscience. 2014; 8: 38

[90] Busardò FP, Kyriakou C, Cipolloni L, Zaami S, Frati P. From Clinical Application to Cognitive Enhancement: the Example of Methylphenidate. Current Neuropharmacology. 2016; 14: 1727.

[91] Franke AG, Lieb K, Hildt E. What users think about the differences between caffeine and illicit/prescription stimulants for cognitive enhancement. PLoS ONE. 2012; 7: e40047.

[92] Lynch G, Palmer LC, Gall CM. The likelihood of cognitive enhancement. Pharmacology, Biochemistry, and Behavior. 2011; 99: 116-129.

[93] Ishizuka T, Sakamoto Y, Sakurai T, Yamatodani A. Modafinil increases histamine release in the anterior hypothalamus of rats. Neuroscience Letters. 2003; 339: 143-146.

[94] Kelley AM, Webb CM, Athy JR, Ley S, Gaydos S. Cognition enhancement by modafinil: a meta-analysis. Aviation, Space, and Environmental Medicine. 2012; 83: 685-690.

[95] Savulich G, Piercy T, Brühl A, Fox C, Suckling J, Rowe J, et al. Focusing the Neuroscience and Societal Implications of Cognitive Enhancers. Clinical Pharmacology \& Therapeutics. 2017; 101: $170-172$.
[96] Heinz A, Kipke R, Müller S, Wiesing U. True and false concerns about neuroenhancement: a response to 'Neuroenhancers, addiction and research ethics', by D M Shaw. Journal of Medical Ethics. 2014; 40: 286-287.

[97] Hildt E, Lieb K, Bagusat C, Franke AG. Reflections on Addiction in Students Using Stimulants for Neuroenhancement: a Preliminary Interview Study. BioMed Research International. 2015; 2015: 621075.

[98] Swanson JM, Volkow ND. Increasing use of stimulants warns of potential abuse. Nature. 2008; 453: 586.

[99] Teter CJ, McCabe SE, LaGrange K, Cranford JA, Boyd CJ. Illicit use of specific prescription stimulants among college students: prevalence, motives, and routes of administration. Pharmacotherapy. 2006; 26: 1501-1510.

[100] Bagusat C, Kunzler A, Schlecht J, Franke AG, Chmitorz A, Lieb K. Pharmacological neuroenhancement and the ability to recover from stress - a representative cross-sectional survey among the German population. Substance Abuse Treatment, Prevention, and Policy. 2018; 13: 37.

[101] Ilieva I, Boland J, Farah MJ. Objective and subjective cognitive enhancing effects of mixed amphetamine salts in healthy people. Neuropharmacology. 2013; 64: 496-505.

[102] Cropsey KL, Schiavon S, Hendricks PS, Froelich M, Lentowicz I, Fargason R. Mixed-amphetamine salts expectancies among college students: is stimulant induced cognitive enhancement a placebo effect? Drug and Alcohol Dependence. 2017; 178: 302-309.

[103] Dawkins L, Shahzad F, Ahmed SS, Edmonds CJ. Expectation of having consumed caffeine can improve performance and mood. Appetite. 2011; 57: 597-600.

[104] Schleim S, Quednow BB. How Realistic are the Scientific Assumptions of the Neuroenhancement Debate? Assessing the Pharmacological Optimism and Neuroenhancement Prevalence Hypotheses. Frontiers in Pharmacology. 2018; 9: 3.

[105] Sakakibara E. The polysemy of psychotropic drugs: continuity and overlap between neuroenhancement, treatment, prevention, pain relief, and pleasure-seeking in a clinical setting. BMC Medical Ethics. 2020; 21: 54.

[106] Maier LJ, Haug S, Schaub MP. The importance of stress, self-efficacy, and self-medication for pharmacological neuroenhancement among employees and students. Drug and Alcohol Dependence. 2015; 156: 221-227.

[107] Randall DC, Viswanath A, Bharania P, Elsabagh SM, Hartley DE, Shneerson JM, et al. Does Modafinil Enhance Cognitive Performance in Young Volunteers who are not Sleep-Deprived? Journal of Clinical Psychopharmacology. 2005; 25: 175-179.

[108] Turner DC, Robbins TW, Clark L, Aron AR, Dowson J, Sahakian BJ. Cognitive enhancing effects of modafinil in healthy volunteers. Psychopharmacology. 2003; 165: 260-269.

[109] Béracochéa D, Celerier A, Borde N, Valleau M, Peres M, Pierard C. Improvement of learning processes following chronic systemic administration of modafinil in mice. Pharmacology, Biochemistry, and Behavior. 2002; 73: 723-728.

[110] Solanto MV. Arnsten AFT, Castellanos FX. Comparative psychopharmacology of methylphenidate and related drugs in human volunteers, patients with ADHD and experimental animals. In Stimulant Drugs and ADHD: Basic and Clinical Neuroscience (pp. 303-331). USA: Oxford University Press. 2001.

[111] Arnsten AFT, Li B. Neurobiology of executive functions: catecholamine influences on prefrontal cortical functions. Biological Psychiatry. 2005; 57: 1377-1384.

[112] Bertozzi G, Salerno M, Pomara C, Sessa F. Neuropsychiatric and Behavioral Involvement in AAS Abusers. A Literature Review. Medicina. 2019; 55: 396.

[113] Schiavone S, Neri M, Mhillaj E, Pomara C, Trabace L, Turillazzi $\mathrm{E}$. The role of the NADPH oxidase derived brain oxidative stress in the cocaine-related death associated with excited delirium: a literature review. Toxicology Letters. 2016; 258: 29-35.

[114] Pomara C, Neri M, Bello S, Fiore C, Riezzo I, Turillazzi E. Neurotoxicity by synthetic androgen steroids: oxidative stress, apoptosis, and neuropathology: a review. Current Neuropharmacology. 2015; 13: 132-145. 
[115] Piacentino D, Kotzalidis GD, Del Casale A, Aromatario MR, Pomara C, Girardi P, et al. Anabolic-androgenic steroid use and psychopathology in athletes. A systematic review. Current Neuropharmacology. 2015; 13: 101-121.

[116] Zammit C, Muscat R, Sani G, Pomara C, Valentino M. Cerebral white matter injuries following a hypoxic/ischemic insult during the perinatal period: pathophysiology, prognostic factors, and future strategy of treatment approach. A minireview. Current Pharmaceutical Design. 2015; 21: 1418-1425.

[117] Orban G, Bombardi C, Marino Gammazza A, Colangeli R, Pierucci M, Pomara C, et al. Role(s) of the 5-HT2C receptor in the development of maximal dentate activation in the hippocampus of anesthetized rats. CNS Neuroscience and Therapeutics. 2014; 20: 651-661.

[118] Turillazzi E, Bello S, Neri M, Pomara C, Riezzo I, Fineschi V. Cardiovascular effects of cocaine: cellular, ionic and molecular mechanisms. Current Medicinal Chemistry. 2012; 19: 5664 5676.

[119] Pomara C, Cassano T, D’Errico S, Bello S, Romano AD, Riezzo I, et al. Data available on the extent of cocaine use and dependence: biochemistry, pharmacologic effects and global burden of disease of cocaine abusers. Current Medicinal Chemistry. 2012; 19: 5647-5657.

[120] Neri M, Cantatore S, Pomara C, Riezzo I, Bello S, Turillazzi E, et al. Immunohistochemical expression of proinflammatory cytokines IL-1 $\beta$, IL-6, TNF- $\alpha$ and involvement of COX-2, quantitatively confirmed by Western blot analysis, in Wernicke's encephalopathy. Pathology, Research and Practice. 2011; 207: 652-658.

[121] Turillazzi E, La Rocca G, Anzalone R, Corrao S, Neri M, Pomara C, et al. Heterozygous nonsense SCN5a mutation W822X explains a simultaneous sudden infant death syndrome. Virchows Archiv. 2008; 453: 209-216.

[122] Turillazzi E, Baroldi G, Silver MD, Parolini M, Pomara C, Fineschi V. A systematic study of a myocardial lesion: colliquative myocytolysis. International Journal of Cardiology. 2005; 104: 152-157.

[123] Fineschi V, Silver MD, Karch SB, Parolini M, Turillazzi E, Pomara C, et al. Myocardial disarray: an architectural disorganization linked with adrenergic stress? International Journal of Cardiology. 2005; 99: 277-282.

[124] Sessa F, Salerno M, Cipolloni L, Bertozzi G, Messina G, Mizio GD, et al. Anabolic-androgenic steroids and brain injury: miRNA evaluation in users compared to cocaine abusers and elderly people. Aging. 2020; 12: 15314-15327.

[125] Sessa F, Messina G, Russo R, Salerno M, Castruccio Castracani $\mathrm{C}$, Distefano A, et al. Consequences on aging process and human wellness of generation of nitrogen and oxygen species during strenuous exercise. Aging Male. 2020; 23: 14-22.

[126] Sessa F, Maglietta F, Bertozzi G, Salerno M, Di Mizio G, Messina G, et al. Human Brain Injury and miRNAs: an Experimental Study. International Journal of Molecular Sciences. 2019; 20: 1546.

[127] Sessa F, Franco S, Picciocchi E, Geraci D, Chisari MG, Marsala $\mathrm{G}$, et al. Addictions substance free during lifespan. Acta Medica Mediterranea. 2018; 4: 2135-2142.

[128] Albano GD, Amico F, Cocimano G, Liberto A, Maglietta F, Esposito $\mathrm{M}$, et al. Adverse Effects of Anabolic-Androgenic Steroids: A Literature Review. Healthcare. 2021; 9: 97.

[129] Patanè FG, Liberto A, Maria Maglitto AN, Malandrino P, Esposito M, Amico F, et al. Nandrolone Decanoate: Use, Abuse and Side Effects. Medicina. 2020; 56: 606.

[130] Torrisi M, Pennisi G, Russo I, Amico F, Esposito M, Liberto A, et al. Sudden Cardiac Death in Anabolic-Androgenic Steroid Users: A Literature Review. Medicina. 2020; 56: 587.

[131] Salerno M, Villano I, Nicolosi D, Longhitano L, Loreto C, Lovino A, et al. Modafinil and orexin system: interactions and medico-legal considerations. Frontiers in Bioscience (Landmark Edition). 2019; 24: 564-575.
[132] Fond G, Fajula C, Dassa D, Brunel L, Lançon C, Boyer L. Potentially inappropriate psychotropic prescription at discharge is associated with lower functioning in the elderly psychiatric inpatients. A cross-sectional study. Psychopharmacology. 2016; 233: 2549-2558.

[133] Sandi C, Rose SPR. Training-dependent biphasic effects of corticosterone in memory formation for a passive avoidance task in chicks. Psychopharmacology. 1997; 133: 152-160.

[134] McGaugh JL, Roozendaal B. Role of adrenal stress hormones in forming lasting memories in the brain. Current Opinion in Neurobiology. 2002; 12: 205-210.

[135] Lieberman H, Tharion W, Shukitt-Hale B, Speckman K, Tulley R. Effects of caffeine, sleep loss, and stress on cognitive performance and mood during U.S. Navy SEAL training. Sea-AirLand. Psychopharmacology. 2002; 164: 250-261.

[136] Tomažič T, Čelofiga AK. Ethical aspects of the abuse of pharmaceutical enhancements by healthy people in the context of improving cognitive functions. Philosophy, Ethics, and Humanities in Medicine. 2019; 14: 7.

[137] Cakic V. Smart drugs for cognitive enhancement: ethical and pragmatic considerations in the era of cosmetic neurology. Journal of Medical Ethics. 2009; 35: 611-615.

[138] Cheshire WP. Drugs for enhancing cognition and their ethical implications: a hot new cup of tea. Expert Review of Neurotherapeutics. 2006; 6: 263-266.

[139] Trenque T, Herlem E, Abou Taam M, Drame M. Methylphenidate off-label use and safety. SpringerPlus. 2014; 3: 286.

[140] Sharif S, Guirguis A, Fergus S, Schifano F. The Use and Impact of Cognitive Enhancers among University Students: A Systematic Review. Brain Sciences. 2021; 11: 355.

Abbreviations: ADHD, attention deficit hyperactivity disorder; IQ, intelligence quotient; cAMP, Cyclic adenosine monophosphate.

Keywords: Smart drugs; Neuroenhancement; Cognitive enhancement; Brain effect; Incidence; Nootropics

Send correspondence to: Francesco Sessa, Department of Clinical and Experimental Medicine, University of Foggia, 71122 Foggia, Italy, E-mail: francesco.sessa@unifg.it

Send correspondence to: Monica Salerno, Department of Medical, Surgical and Advanced Technologies "G.F. Ingrassia”, University of Catania, 95121 Catania, Italy, Email: monica.salerno@unict.it

${ }^{\dagger}$ These authors contributed equally. 